\title{
STATEMENT TO THE COMMONWEALTH BY THE FIJI PEOPLE'S COALITION GOVERNMENT
}

Hon. Pratap Chand and Hon. Jokapeci Koroi

A statement made to the Secretary-General, Commonwealth Secretariat, Mr Don McKinnon, and Members of the Commonwealth Ministerial Action Group

\section{Introduction}

We submit the following statement for urgent consideration by the Commonwealth Ministerial Action Group, scheduled to meet on 6 June 2000.

We regard the convening of the CMAG meeting as a clear and very welcome signal of the level of concern shown by the Commonwealth about the current crisis in the Fiji Islands, in particular the unlawful and unconstitutional overthrow of the democratically elected People's Coalition government by terrorists on Friday 19 May, and the holding of our Prime Minister and Government as hostages for the past two weeks.

Brief overview of developments since 19 May 2000

(i) the principal demands of the terrorists led by speight were the dismissal of the Prime Minister and the elected Government; the abrogation of the Constitution; amnesty for Speight and co-conspirators; the establishment of ethnic Fijian paramountcy within 
a new constitution; and the appointment of a new exclusively ethnic Fijian Government. Speight has persistently insisted the release of the hostages was conditional on these demands being met.

(ii) Following the takeover of Parliament and the taking of hostages including the Prime Minister and members of his Cabinet, the Coalition pledged its support to the President in his decision to assume executive authority and to declare a state of emergency. This course of action appeared to be the best possible alternative in view of the crisis facing the country at the time.

(iii) On Saturday 27 May, following resolutions of the Bose Levu Vakaturaga (Council of Chiefs), the President adopted a course of action which resulted in the dismissal of the Prime Minister and Cabinet and the suspension of Parliament. The Government rejected this course of action and made its position clear to the President. We argued that it would have the effect of legitimising the overthrow of a constitutional and democratically elected government by terrorists.

In support of our position, we submitted to the President copies of three opinions by international constitutional experts, all of which confirmed that the President's powers under the Constitution did not extend to the dismissal of the Prime Minister and his Cabinet or the suspension of the Parliament. His actions were unequivocally unlawful and unconstitutional.

(iv) The dismissal of the Prime Minister by the President followed resolutions passed by the Bose Levu Vakaturaga (Council of Chiefs). The constitutional powers of the BLV are in fact restricted to the appointment of 14 members of the Senate (section 64 (1) a), and the appointment and removal of the President (s.90 and s.93). We advised the President of these limitations on the BLV's powers.

In essence, the BLV does NOT have the power to remove the government or the Prime Minister. Nor does it have the authority to demand or endorse any political configuration that follows from such action.

(v) Following the takeover of Parliament, supporters of the terrorists plunged the country into orchestrated violence, looting, arson, ransacking, 
hijacking of vehicles, and other shocking acts of terrorism, targeting innocent people and whole communities - especially Indo-Fijians.

(vi) The military intervention this week was ostensibly aimed at restoring law and order. The Coalition totally rejects this argument. Firstly, the military did not intervene to restore law and order when the Government was unlawfully taken captive by the terrorists. Moreover, during the 10 days that ensued after the takeover, the military demonstrated very clearly that it was unwilling to restore law and order.

secondly, the military has taken the drastic and quite unnecessary action of removing the President, assuming executive authority itself, and abrogating the Constitution. Further, it has offered an amnesty to the terrorists and engaged in negotiations with them about the composition of an interim military-appointed government as well as the process of developing a new Constitution. The military has agreed to a number of Speight's choices for the proposed interim government.

We reject all these actions taken by the Fiji Military Forces as unlawful and unconstitutional. They make it abundantly clear that the military has a clear political agenda that goes well beyond its professed intention to restore law and order.

(vii)The actions taken by the President, the BLV and the Fiji Military Forces have not been directed at solving the hostage crisis, upholding the Constitution, and restoring the democratically elected government. On the contrary, they manifestly support the principal demands of the terrorists which were aimed at unlawfully overthrowing a democratic government and the Constitution, in furtherance of the personal agendas of a few agitators.

\section{People's Coalition Submission}

(i) We wish to remind the CMAG of the special features of the Fiji Islands Constitution and its respected standing in the international community, especially in the Commonwealth, for its commitment to the core international principles of equality, non-discrimination, human rights, and social and economic rights. 
At the heart of our Constitution lies a very comprehensive Bill of Rights, including unparalleled provisions on racial discrimination and torture. We are very proud of this.

In terms of process, the constitution is the product of five years of consultations and consensus building. The specific content is the product of joint negotiations between all political parties, and they took place under the former SVT government and its Prime Minister, Rabuka (who has this week been appointed by the FMF Commander as a member of the Military Council of Advisers). The Constitution was unanimously approved by both houses of Fiji's Parliament, and the Council of Chiefs, and subsequently endorsed by the Commonwealth.

The origins of our Constitution are grounded in the painful lessons of the 1987 coups. The overriding purpose was to ensure that we never had to endure the horrors of a coup again. Another key objective was to give an unequivocal constitutional commitment to addressing issues of concern that emerged in 1987, including ethnic disparities and the need to include strong provisions for affirmative action on behalf of indigenous Fijians, and the further constitutional entrenchment of the protection of indigenous rights.

Indeed the constitution is hailed as an exemplary model for the protection and advancement of indigenous rights by the international community.

(ii) We are now effectively dealing with an illegal and unconstitutional overthrow of government, supported by various institutions of the state, including the military, and the unlawful abrogation of our Constitution. Any international support for the recent (or future) actions of the Fiji Military Forces outside its 'law and order' mandate would legitimise the overthrow of democracy and constitutional government. It would give recognition to an unlawful and unconstitutional regime.

(iii) The overthrow of a constitutional and democratically elected government by the military (through the support of a terrorist group using hostages) offends international standards including the core civil and political rights embraced by the Commonwealth. As you well know, 
these cherished principles have been restated and enhanced over the last decade, especially through the Millbrook Commonwealth Action Programme.

(iv) It is crucial that the integrity of these international commitments to democracy, good governance, human rights and the rule of law are vigilantly defended by the Commonwealth. The Harare Commonwealth Declaration now stands fundamentally violated in the Fiji Islands. The situation demands an urgent and principled response by the Commonwealth, through the CMAG.

Failure to do this will without doubt result in:

- a total breakdown of law and order and a descent into anarchy

- a rapid degeneration into institutionalised racial discrimination

- ethnic persecution and serious human rights violations both by the security forces and armed vigilante groups

- victimisation and harassment of government members and supporters, and the Indo-Fijian community in general

- a flaring-up of hostile provincialism (tribalism) within the ethnic Fijian community including the setting up of a separate state by the western provinces which strongly supports the elected People's Coalition government

- a rapid decline in the integrity of Fiji's judiciary, public service and all accountability institutions.

(v) We have high, and we know justified, hopes that the CMAG and the Commonwealth will give a clear and decisive commitment to being the principal intermediary in securing a satisfactory outcome of the crisis, consistent with our Constitution and the Harare Principles.

Specifically, we ask you to invoke your mandate and related operational machinery to help restore the constitutional and democratically elected government and uphold our Constitution. 
(vi) We therefore look to the CMAG to take action along the following lines:

- Continue to recognise the People's Coalition under the leadership of Prime Minister Mahendra Chaudhry as the legitimate Government of the Fiji Islands. This would be consistent with the Commonwealth's decision on Sierra Leone in 1997. It would also be in line with the principles of the Harare Declaration.

- Warn the Fiji Military Forces that its failure to restore the democratically elected People's Coalition government and the 1997 Constitution will result in the imposition of the full force of the Commonwealth and international sanctions against the illegal regime set up by the Fiji Military Forces.

- Specify that these sanctions will include

i) Fiji's expulsion from the Commonwealth

ii) A unified suspension of diplomatic relations with the illegal regime set up by the Fiji Military Forces by member states

iii) Suspension of technical assistance, development aid and other assistance or support by member states and the Commonwealth Secretariat

iv) A Commonwealth commitment to pursuing further diplomatic, political and economic isolation of the illegal regime through the United Nations and other international agencies.

If this does not happen by the time of your meeting on Monday (6 June 2000), we ask that the CMAG call for the unconditional and immediate release of hostages.

If the Fiji Military Forces do not restore the elected government and the 1997 Constitution, we ask that the Commonwealth take necessary measures in response, including the setting up and rapid deployment of a peacekeeping force.

We stress the need to act now, without further delay, before the situation deteriorates very rapidly. 


\section{Conclusion}

Our Government and the vast majority of Fiji citizens of all ethnic groups cherish our membership of the Commonwealth. In our time of crisis, we look to the commonwealth to uphold the integrity of its Charter and, accordingly, to take firm, decisive and principled action to help restore constitutional government in our beloved country. 